UDC 577.214/218; 616.006.6

\title{
Circular RNA: the rings of power over cell
}

\author{
V. V. Gordiyuk, O. S. Mankovska \\ Institute of Molecular Biology and Genetics, NAS of Ukraine \\ 150, Akademika Zabolotnoho Str., Kyiv, Ukraine, 03143 \\ vasilij_gordiyuk@yahoo.com
}

\begin{abstract}
Circular RNAs (circRNAs) are endogenous covalently closed single-stranded noncoding RNAs (ncRNAs) without the 5'-cap and 3'-poly(A) tail derived from alternative mRNA splicing. CircRNAs are expressed across all branches of evolutionary tree, including viruses and prokaryotes, and are evolutionary conserved. CircRNAs have a constitutive al biological role. In this review, we summarized the latest data on circRNAs and highlighted their most important and studied functions in different biological processes.
\end{abstract}

Keyword s: Circular RNA (circRNA), RNA binding proteins (RBPs), backsplicing model, lariat model, the circulating cell-free RNA, cancer-related circRNA

\section{Introduction}

The immense world of non-coding RNAs (ncRNAs) is full of surprises for researchers. In previous studies, scientists usually focused on the linear ncRNAs, such as long noncoding RNAs (lncRNAs) and micro-RNAs (miRNAs), especially after it was shown, that these linear ncRNAs have multiple functions in physiological and pathological processes $[1,2]$. However, in the last decade circular non-coding RNAs attracted the attention of researchers due to the discovery of their unprecedented abundance and great diversity of forms and functions.

The circular RNAs (circRNAs) are considered as a class of endogenous covalently closed single-stranded non-coding RNAs without the 5'-cap and 3'-poly(A) tail, which are derived from alternative mRNA splicing. The circRNAs are ubiquitous and play the constitutive and different biological roles [3, 4].

The first covalently closed RNA circles were discovered in the potato spindle tuber viroid in 1967 [5]. These circRNA-containing viroids are quite small (220-400 nucleotides) and are specialized exclusively on infecting the plant cells, replicating autonomously within the nucleus or chloroplasts of their host cells. Their genome forms the self-complementary base-paired rod-like structures [6]. In 1976, the circRNA was found in the Sendai virus [7].

(C) 2020 V. V. Gordiyuk et al.; Published by the Institute of Molecular Biology and Genetics, NAS of Ukraine on behalf of Biopolymers and Cell. This is an Open Access article distributed under the terms of the Creative Commons Attribution License (http://creativecommons.org/licenses/by/4.0/), which permits unrestricted reuse, distribution, and reproduction in any medium, provided the original work is properly cited 
The decade later, in 1986, Hepatitis delta $(\delta)$ virus (HDV) was considered to contain circRNA-encoded genome [8]. HDV is a satellite virus of the human Hepatitis B Virus (HBV) and the HBV envelope proteins (HBsAg) are necessary for it to form virus particles. The Hepatitis Delta virion was shown to be circular, single-stranded, negative sense RNA, composed of approximately $1700 \mathrm{bp}$ [9]. HDV genome encodes a single open reading frame, which is translated to regulate viral replication [10].

In 1988, the circRNAs were described as products or intermediates of rRNA maturation in prokaryotes [11]. In thermophilic archaea their circular, protein-bound structure could evolve as protection from heat denaturation [12, 13]. Except viruses and prokaryotes, the circRNAs are also expressed across all branches of the eukaryotic tree of life.

The proper eukaryotic circRNAs were first detected by electron microscopy in cytoplasm of the human HeLa cells in 1979 by scientists at the Rockefeller University [14]. Later on, it was shown, that circRNAs are also present in protists $[15,16]$ and fungi, such as yeast [17]. Furthermore, circRNAs were described as intermediates of tRNA maturation in unicellular red algae [18]. In 1991, the first endogenous circRNAs, which are expressed in higher eukaryotes, were identified [19]. In 1993, it was also demonstrated, that circRNAs may rise by the splicing error of a human ets-1 proto-oncogene [20]. In 2012, it was shown that circRNAs can be the transcriptional products of thousands of human genes and in hundreds of cases constituted the dominant RNA isoform [21].

\section{The classification and characteristics of circRNAs}

Generally, expression of $20 \%$ of eukaryotic genes, which are currently active in a cell, is associated with circRNA production $[22,23]$.

Today the circRNAs can be generally divided into eight categories according to their origin: exonic circRNAs (ecircRNA) [24], circular RNAs from introns (ciRNAs) [25], exonintron circRNAs (EIciRNA) [26], intergenic circRNAs [27], interior circRNAs (i-circRNAs) [28], antisense circRNAs (as-circRNAs) [4], tRNA intronic circRNA (tricRNAs) [29], and fusion circRNAs (f-circRNAs) [30] (see table 1 for details).

EcircRNAs are accounting for approximately $85 \%$ of all types of circRNAs [31]. Up to six exons could be spliced in inverted order within one circRNA [32]. The exonic circRNA molecules range from 100 to over 4000 nucleotides; the size of intronic circRNAs varies from 200 to over 3000 nucleotides [33]. Majority of exonic circRNAs are often located in the cytoplasm, while a small part of circRNAs, consisting of introns, could be found in the nucleus [24].

CircRNAs are extremely abundant and possess great diversity: more than 20000 different circRNAs were identified in eukaryotes by high-throughput sequencing and novel computational approaches for non-polyadenylated RNA transcripts [24]. The fluorescent in situ hybridization (FISH/ISH) techniques can be also used for detection of the circRNA transcript with a DNA oligo probe in the cells or tissue samples [34].

CircRNAs are more stable than their cognate linear mRNAs. The average lifetime of $3^{\prime} \rightarrow 5^{\prime}$-linked circRNAs is $19-24 \mathrm{~h}$, however, 
it can be up to $48 \mathrm{~h}$ [35]. This is $2-5$ fold longer (in certain cases - up to 10-fold) compared to the linear mRNAs, that have the average lifetime of 4-9 h [36].

On a genome-wide level, usually $3-10$ circRNA isoforms are produced per gene [37]. CircRNAs are usually expressed at low levels, compared with messenger RNAs (mRNAs). The vast majority $(>90 \%)$ of circRNAs are present as just 1-10 molecules per cell [38]. The length of the mature circRNA dictates the mode of nuclear export [39].

CircRNAs are usually expressed in cellspecific and tissue-specific manners [40]. In the study of nematode embryogenesis several circRNAs, present in oocytes, were not expressed later in 1- or 2-cell embryos, which is the evidence of their potential role in developmental processes [41]. In adult, non-pathological (normal) tissues expression of circRNAs is characterized by conservation and complexity [42]. CircRNAs are evolutionarily conserved at the sequence level among different species [43].

A number of research works were concentrated on explaining the mechanism of transcript circularization, especially on characterization of genomic sequences which can generate circular transcripts. One of the observations, that explained the mechanism of circularization, was the link between repetitive elements and circular RNA biogenesis. This link was first described in the mouse Sry locus, which produced circRNA when it was flanked by repetitive complementary sequences, and lost this ability when repeats were completely removed [44], later such phenomenon was discovered for human and plant circRNAs.

The most widespread repetitive elements in human genome are Alu repeats. By the means of computational analysis, it was found that human exons that encode circRNAs are flanked by introns enriched in Alu elements, and approximately $90 \%$ of human circRNAs have complementary Alu elements in their flanking introns. Therefore, the model of possible circularization was suggested, according to which the intronic repeats may base pair to one another, bringing the splice sites into close proximity [43].

The participation of repetitive elements in regulation of transcript formation can also appear in active manner, due to the fact, that some of these repeats continue to retrotranspose (for instance, LINE 1 and Alu). Thus, the new retrotransposition could switch gene transcription from a protein-coding mRNA to a circular RNA and alter gene function. Such evidence can come as explanation of a number of diseases, associated with retrotransposition insertions even if it does not disrupt gene structure, it can deregulate its function $[45,46]$.

One more way of transposone-associated circRNA biogenesis is connected with their ribozyme activity. The new family of genomeencoded circRNAs (self-cleaving or hammerhead rybozymes) was found in plants, and authors described them as small and nonautonomous retrotransposable elements. These ribozymes are spread in plant genomes through small non-coding circRNAs [47].

The existence of circRNAs was demonstrated in blood cells and in cell-free compartments. CircRNAs are significantly enriched in platelets: 17-188-fold, compared with the nucleated tissues [48], that's why they are high in human peripheral whole blood [49]. CircRNAs were also detected in bone marrow cells [50]. More than 1000 circRNAs were 
identified in human serum exosomes. Exosomal circRNAs can participate in cell-to-cell communication as a messenger to mediate multiple signaling pathways [51].

\section{Turnover of circRNAs}

\section{Biogenesis of circRNAs}

Various types of circRNAs are generated in different ways. Up to date, it is known, that more than $95 \%$ of human genes are alternatively spliced [52]. According to existing research data, namely alternative splicing is the main mechanism of circRNA formation. The discovery of inverted, out-of-order spliced exons in ssRNA, referred to as "scrambled exons" in humans [19], gave the first evidence, that these molecules might originate from the protein-coding open reading frames (ORF). However, introns, located in the ORF of a protein-coding gene, also can circularize [53].

In a case of exon-originated circRNAs there were proposed three models of their possible formation: the lariat model [54], backsplicing model and RNA-binding protein (RBP)-driven circularization [55] (Fig. 1).

The model of lariat-driven circularization is based on concept that the exon is skipped along with RNA folding, and exonic circRNAs or EIciRNAs are formed, depending on the removing or keeping introns. When a premRNA is spliced, the 3-hydroxyl of the upstream exon interacts with the 5'-phosphate of the downstream exon to form a covalent linkage, producing a lariat that contains exons and introns. Exon skipping results in production of the mature linear mRNA as well as the intron lariat containing exon. This lariat is re-spliced to generate the mature circRNA as well as a double lariat structure that is subsequently debranched and degraded [54] (Fig. 1, A).

In intron-pairing-driven circularization (basepairing-driven circularization), the formation of exonic circRNAs or EIciRNAs is regulated by base pairing in introns on both sides of premRNA (Fig. 1, B). Base pairing between downstream introns and upstream introns (based on inverse-repeating or complementary sequences) results in back-splicing and production of the circRNA, containing the single or multiple exons $[55,24]$. The introns are removed or retained to form ecircRNA or EIciRNA.

The last of existing exonic circRNA generation models proposes the involvement of RNA-binding proteins (RBPs) and following RBP-driven circularization. RBPs can bind to the specific sequence of introns, shorten the distance between the donor site and the receptor site, and initiate the biogenesis of ecircRNA [55] (Fig. 1, C).

Non-exonic circRNAs can be formed either from introns of one gene, or from non-exonic sequences between two different genes in a case of intergenic circRNA [27] (Fig. 1, D). In the formation of intronic circRNAs, the intron lariat is formed with the combination of conserved motifs, located upstream and downstream of introns (7-nt GU-rich element and 11-nt C-rich element to escape debranching and exonucleolytic degradation) [25] (Fig. 1, E). Interestingly, tRNA intronic circRNAs acquire their stable circular structure via pre-tRNA splicing. The introns, which were removed during this process, then circularize using backsplicing mechanism [29] (Fig. 1, F).

The biogenesis of circRNAs is also regulated by splicing factors. At the same time, these RNA molecules in some cases regulate 
alternative splicing, which helps to maintain the balance between circRNA biogenesis and canonical splicing [56].

\section{Export and possible way of degradation of circRNAs}

CircRNAs are exported to the cytoplasm by RNA helicase URH49 or ATP-ase UAP56 $[57,58]$.

CircRNAs can be degraded by endonucleases. MicroRNA/RISC/AGO2-mediated cleavage could be a dominant degradation mechanism. For example, the circRNA produced from the CDR1as transcript is targeted for degradation by the miR-671, that guided the cleavage [59].

There is another possible pathway of circRNAs degradation, induced by selective context-dependent posttranscriptional meth- ylation of adenosines in RNAs. The following recruitment of the YTHDF2 protein to N6methyladenosine (m6A) relocates affected mRNAs to P-bodies for degradation [60].

Additionally, the transport by the extracellular vesicles might be also implicated in reduction of cellular circRNA content. Expulsion of circRNAs into the extracellular space by exosomes can be a way to clear and degrade circRNAs. Alternatively, exosome can protect circRNA from degradation [61].

\section{The interactions between circRNAs and proteins}

The interactions between circRNAs and proteins are mainly analyzed by the RNA pulldown assay or RNA immunoprecipitation (RIP). Also, studies of co-localization between circRNAs and proteins, using fluorescent mi-
Exonic circRNA

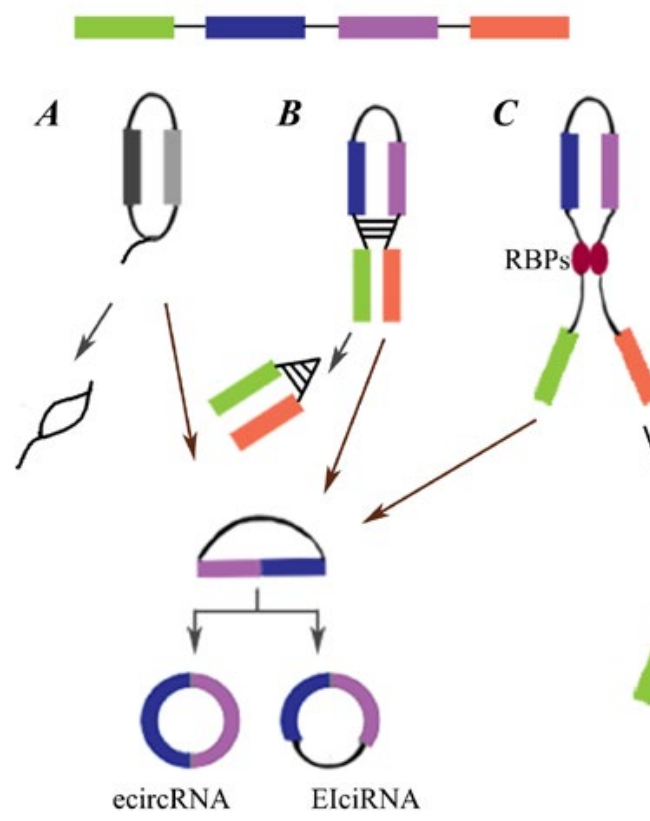

Intronic circRNA

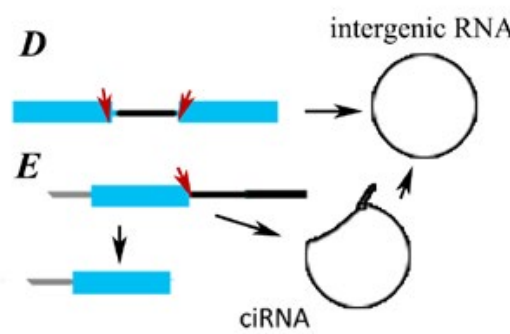

tricRNA

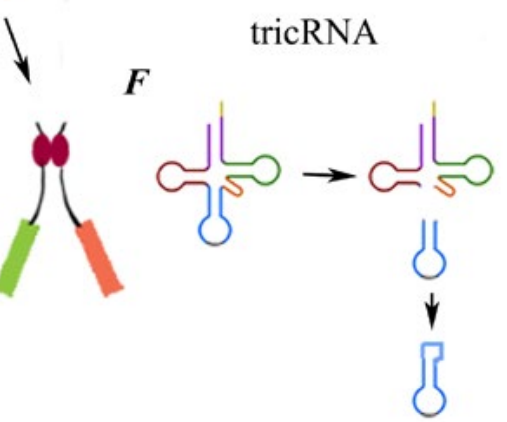

Fig. 1. Biogenesis of circRNAs. The ways of biogenensis of ecircRNAs and ElciRNAs: (A) - lariat-driven, (B) - by intron pairing, $(\mathrm{C})$ - through binding RBPs (D) The biogenensis of intergenic circRNAs. (E) The biogenensis of ciRNAs. (F) The generation of tricRNA.

Abbreviations: circRNAs - circular RNAs; ecircRNAs - exonic circRNAs; ElciRNAs - exon-intron circRNAs; ciRNAs - circular intronic RNAs; RBPs - RNAbinding proteins; tricRNA - tRNA intronic circular RNAs. 
croscopy, were performed, to demonstrate the close proximity of these molecules [62].

RBPs represent a broad class of proteins involved in gene transcription and translation; they contain different types of domain motifs [63]. RBPs regulate almost every aspect of the circRNA lifecycle: splicing, processing, folding, stabilization, localization and degradation [64].

Vice versa, circRNAs can regulate expression and function of RBPs. CircRNAs display a variety of functions in different tissues or at developmental stages, via binding with various functional proteins. CircRNAs may bind, store, sort, and sequester proteins to particular subcellular locations, and also act as dynamic scaffolding molecules, modulating proteinprotein interactions [62].

The highly conserved RNA-editing enzyme ADAR (Adenosine deaminase acting on RNA) binds the double-stranded RNAs by targeting Alu repeats in human cells. ADAR1 antagonizes circRNA biogenesis through A-to-I editing of intron pairs flanking circularized exons, thus diminishing the complementarity and stability of these intron pairs' interactions [65]. DHX9, an abundant nuclear RNA helicase, has the unique domain organization, resembling ADAR. Silencing of DHX9 leads to increased circRNA production [66].

RNA binding protein FUS regulates circRNA formation by binding introns, flanking back-splicing junctions [67]. CircRNA production is further controlled by serine-arginine (SR) proteins [68]. For instance, heterogeneous nuclear ribonucleoprotein L (HNRNPL) regulates the alternative splicing of multiple RNAs and is involved in the regulation of circRNAs in prostate cancer [69]. Quaking (QKI), as a kind of alternative splicing factor, promotes
circRNA generation by binding to its intronic binding motifs [70]. RBPs are involved in transcriptional regulation of target genes and also in post-transcriptional regulation [71]. CircRNAs function as the miRNA sponges with the help of Ago, one of the RBPs [72]. CircRNAs compete with mRNA to combine with RBP, to influence the mRNA translation. These two kinds of molecules also regulate the specific modifications (DNA-methylation) [73]. Additionally, RBPs are involved in the potential extracellular transport pathway [64].

\section{A dynamic circRNA-protein interaction.}

CircRNA-protein interactions are dependent on the variety of the circRNA tertiary structures in various cell/tissue environments, resulting in higher protein binding capacity, than those of linear RNA sequences [62].

Endogenous cytosolic circRNA, a circular transcript from forkhead box O3 (circ-Foxo3) can facilitate, localize and regulate functions of the proteins. The major tertiary structure of circ-Foxo3 allows binding to the stress related proteins in cardiomyocytes and cardiac fibroblasts. Expression of circ-Foxo3 results in reduced nuclear translocation of transcription factors E2F1 and HIF- $\alpha$ and also in induction of cardiac senescence [74]. Moreover, this circFoxo3 structure is responsible for binding to Mdm2 (the E3 ubiquitin-protein ligase) and p53 in a breast cancer cell line. By binding with these proteins, circ-Foxo3 acts like protein scaffold and promotes poly-ubiquitination and degradation of p53 [62, 75]. Also, circ-Foxo3 controls its interaction with p21 and CDK1 in mouse fibroblast NIH3T3, via forming ternary complexes with p21 and CDK2 resulting in repression of the cell cycle entry [76]. 


\section{Role of RBPs in circRNA cell-to-cell} transmission

Various RBPs can be critical factors for the promotion of circRNA transmission in the parent cells [64]; they can serve as the intra-cellular inducers of circRNA, loaded in exosomes in the recipient cell. For example, two circRNAs, KIRKOS-73 and KIRKOS-71, are encoded by the $W W O X$ parent tumor suppressor gene and transferred by exosomes, regulating p53 expression in the recipient cells [77]. So, parent cells may influence RBP expression in the recipient cells and regulate their circRNA biogenesis via exosome secretion [70]. RBPs may conceivably be necessary for compacting the relatively large nucleic acid structures into the small interior spaces of exosomes [78].

\section{Functions of circRNAs}

Accounting the multiplicity of the ways of biogenesis and origins of circRNAs it is not surprising, that their functions are also multiple and diverse. We divided them into several main categories. Yet, some of investigated functions of circRNAs are difficult to categorize, so we listed them separately.

1. Circular RNAs can be involved in regulation of gene expression though direct and indirect mechanisms. The most studied examples are described here:

a) CircRNAs can function to adsorb miRNAs (miRNA sponge) and regulate the target genes of those miRNAs by this mechanism. This model was proposed in 2013 [72]. The example is the circular transcript CDR1as (ciRS-7), which contains 66 selectively conserved miRNA target sites [4]. Moreover, several circRNAs possess microRNA response elements (MREs), which enable them to interact with miRNAs to govern target gene expression [79].

b) At the same time, certain circRNAs could also serve as a miRNA reservoir, contributing to their stabilization [80].

c) Several ciRNAs and ElciRNAs can directly act as transcriptional regulators. The mechanism of action of intronic circRNAs in the nucleus suggests a new cis-regulatory role for circular transcripts in expression of their parental coding genes. It was shown, that some circRNAs, for example ci-ankrd52 and ci-sirt7, are associated with the PolII elongation complex and also specifically associated with phosphorylated PolII. In this way they can positively regulate Pol II transcription of their parent genes [25]. ElciRNAs, such as circEIF3J and circPAIP2, also regulate their parental genes by specific RNA-RNA interaction between U1 snRNA and ElciRNA. It results in formation of the complex between RNA polymerase II and U1 snRNP and in increased expression of the parental genes of ELciRNAs [26].

d) Additionally, circRNAs can regulate alternative splicing by binding to DNA [81]. CircMbl biogenesis competes with pre-mRNA splicing [56].

2. CircRNAs can bind to proteins and work as protein scaffolds and, moreover, regulate their localization [76]. The several examples of it are described here: circ-Foxo3, predominantly localized in the cytoplasm, interacts with ID1, E2F1, HIF1 $\alpha$, and FAK, leading to their cytoplasm retention; circ-Amotl1 can promote the nuclear localization of c-Myc, STAT3, PDK1, and AKT1 by direct interactions with all of them; using its different regions, circ-Dnmt1 can bind to p53 and Auf1 
and facilitate their nuclear localization through the interaction with $\mathrm{HuR}$ protein, circAGO2 facilitates translocation of HuR from the nucleus to the cytoplasm [75]. As single circRNAs can bind to multiple units of RBPs, they serve as stores of RBPs [82].

3. CircRNAs can regulate protein translation: high levels of circPABPN1 derived from PABPN1, repress HuR binding to PABPN1 mRNA through binding to HuR itself, causing a reduction in PABPN1 mRNA translation [71].

4. CircRNAs can encode peptides under certain conditions [83]. In eukaryotic cells, some circRNAs contain an Internal Ribosome Entry Site (IRES) for ribosomal 40S subunits, thus stimulating 5'Cap-independent initiation of translation [38]. Approximately $13 \%$ of the total circRNAs show a N6-methyladenosine (m6A) modification, which drives translation initiation through recruitment of the initiation factor eIF4G2 [84]. These two alternative translation initiation processes of circRNAs are generally activated under cellular stress and promote expression of specific stress response genes [85]. Proteins, translated by circRNA, can act synergistically with the protein expression products of the parental gene and often function together. For example, FBXW7185aa is encoded by circ-FBXW7 and regulates the stability of the c-Myc oncoprotein [86].

Except this, some circRNAs (described for circANRIL) can modulate the ribosomal RNA maturation [87]. CircRNAs also can regulate histone modifications. For instance, circMRPS35 acts as molecular scaffold for KAT7 histone acetyltransferase at the promoters of FOXO1 and FOXO3a and mediates acetylation of H4K5 in this region [88]. Additionally, some circRNA can be reverse-transcribed in vivo into cDNA and integrated into the genome to generate a circRNA-derived pseudogene, playing an important role in cell differentiation and cancer progression [89].

\section{CircRNAs as regulators of physiologi- cal and pathological processes}

The circRNAs play various functions in the cell. They participate in neuronal development and are extraordinarily expressed in the mammalian brain due to a potential to regulate synaptic function [37]. A number of circRNAs can be involved in immune responses, which is described later in this article. A global accumulation of circRNAs during aging was found across different species [90]. CircRNAs can be critical factors for senescence and survival of the cell [91]. Moreover, circRNAs are involved in the age-related diseases, e.g. Alzheimer's disease [92, 28]. Also, many studies connected the presence of circRNAs with cardiovascular diseases [93], diabetes [94], and cancer [95].

\section{Role of circRNAs in development}

For today, the presence of circRNAs has been identified in a number of tissues: nervous tissue, heart and skeletal muscle, and other. Although their functions in different organs are only partially described, the role of their regulation is undoubtedly important, either for the maintenance of organ function and homeostasis or in the development of those tissues.

Analysing Guizhou miniature pig S.scrofacirc RNAs on 0 (D0), 30 (D30) and 240 (D240) days of postnatal development, Liang and coauthors detected 1,489 circRNAs expressed in muscle tissue at different stages of development, but relatively small subset of them (101 and 83, 
respectively) is differently expressed in the D0 versus D30 and D30 versus D240. The difference between D0 and D30 was represented by circRNAs, which can be associated with muscle development, whereas the comparison of the D30 and D240 groups shows that the host genes of differentially expressed circRNAs were associated with homeostatic processes such as ion homeostasis and cation homeostasis. The authors conclude that circRNAs may regulate the growth of muscle tissue during early postnatal muscle development via influence on cell proliferation and fusion [96].

For today, research works discovered functional features of a number of circRNAs, present in human muscles at different stages of development, giving direct or indirect evidence of their roles in myogenesis. Among them circ-ZNF609, circRBFOX2, circSVIL, circLMO7, ciircFUT10, circSNX29, circFGFR4, circFGFR2 and circHIPK3 act like miR sponges, but some of them may play additional role, e.g. circ-ZNF609, which contains the open reading frame, but those mechanisms stay unrevealed yet [97].

Circular isoform of NCX1 is a highly expressed and conserved circRNA. NCX1 is a sodium/calcium exchanger, responsible for transporting calcium out of the cardiomyocyte after contraction. Both qPCR and sequencing data demonstrated, that circular isoforms of NCX1 are induced in the fetal heart and during in vitro cardiomyocyte differentiation [98].

In comparison to other tissues, human brain is characterized by relatively high expression of circRNAs, presumably, due to preferential back-splicing [99]. Chen et al. study of circRNA from embryonic neocortex at early and late stages of its development showed, that
6550 circRNAs were expressed at both stages. Interestingly, $39 \%$ of all expressed genes at the early and late stages also produced circular transcripts. They identified 104 differentially expressed genes across the early and late stages. The strongest differences were observed in expression of circular transcripts of SATB homeobox 2 (SATB2), regulating synaptic membrane exocytosis 1 (RIMS1), and CTC525D6.1, which were significantly up-regulated at the late stage as compared to the early stage. At the same time, the linear forms of listed genes did not expose meaningful differences in their expression among the stages of embryonic brain development. All of these three genes are strongly and specifically devoted to brain tissue functioning and, thus, it was concluded, that the presence of their circular transcripts plays important, but still not fully understood, role in the human fetal brain development [100].

\section{CircRNAs in immune responses}

One of detected implications of circRNAs in immune responseis is the suppression of viral replication and protection from bacterial infection through interaction with pattern recognition receptors (PRRs) - the main receptors of innate immunity. For instance, a recognition receptor RIG-I co-localizes with foreign circRNAs. Exogenous circRNAs can activate a RIG-1-induced cellular immune response pathway, which leads to suppression of viral replication. The mechanism, by which the circular RNA is made, is the key determinant of whether the transcript would be recognized as self or non-self. It predominantly depends on the self introns, which can, irrespective of the exonic sequence, program the circRNA iden- 
tity by defining the set of RNA binding proteins, which mark RNA as "self" [101].

The immune factor NF90/NF110 can promote the circRNA formation by stabilizing the intron complementary sequence. DsRNA binding proteins NF90/NF110 regulate the expression of endogenous circRNAs [102]. Upon viral infection, NF90/NF110 is exported from the nucleus to the cytoplasm; it binds viral transcripts and suppresses viral replication [103]. NF90/NF110 shows the higher affinity to circRNAs, than linear RNAs [102].

Additionally, mcircRasGEF1B can help to protect cells from bacterial infection by enhancing the stability of mature ICAM-1 mRNA [104].

The mentioned ability of circRNAs to function as "microRNA sponges" is the mechanism, by which certain circRNAs are able to increase expression of target proteins, involved in antiviral responses or tumor immunity, such as PD-L1 [105].

CircRNAs also can be involved in differentiation of immune cells. The evidence of such ability is 189 circRNAs, which were found differentially expressed in M1 and M2 macrophages and, thus, can be involved in macrophage differentiation and polarization [106].

\section{CircRNAs in cancer}

Multi-functional cancer-associated circRNAs can possess both oncogene and tumor suppressor properties in tumors. CircRNAs influence the invasive capacity of tumor cells in various ways, including competition with miRNAs, translation into proteins, activity as miRNA reservoirs and formation of the fusion circRNAs $[4,107]$. CircRNAs can also bind to proteins or function as protein decoys in cancer cells. For example, circ-Amotl1 is able to bind and retain $\mathrm{c}-\mathrm{Myc}$ in the nucleus, where it stabilizes c-Myc, up-regulates its target genes, and leads to increased cell proliferation, reduced apoptosis, and a highly tumorigenic phenotype [108].

Expression of circRNA is often associated with the late stage of tumors and poor prognosis. Exosomal circRNAs are also implicated in cancer drug resistance via not fully understood mechanisms. Presumably, they act activating such cellular pathways as WNT and promoting the cell to turn to the stem cell phenotype. As was demonstrated for CRC, exosomes can be transferred from drug-resistant to drug sensitive cell and modulate their chemo-resistance [109].

CircRNAs regulate the epithelial-to-mesenchymal cell transition (EMT). Of note, one of the key mechanisms, by which TWIST1 (the EMT-controlling transcription factor) promotes tumorigenesis, is regulating circRNA [110]. Production of one-third of EMT-related circRNAs was dynamically regulated by QKI, a key RBP in this process [70].

CircRNAs play important roles in cancer progression through modulation of many of the hallmarks of cancer [95]. For example, circFoxo3 induces apoptosis in cancer cell lines [79]. It was shown, that expression of this circular RNA was downregulated in tumors and cancer cell lines in comparison with normal tissues and non-cancerous cells. The mechanism of its action has dual nature and is based on modulation of the poly-ubiquitination function of MDM2: first, it can increase polyubiquitination of mutant $\mathrm{p} 53$, binding to both p53 and MDM2, and second, Foxo3 protein, which does not bind to circFoxo3, is freed from degradation, that leads to increased 
Foxo3 activity, promoting Puma expression and cell apoptosis [75]. Noteworthy, the major tertiary structure models of circ-Foxo3 are different in cancerous and normal cells [62].
CircPRMT5, which acts as a sponge for mir30-c, was found frequently up-regulated in bladder urothelial carcinoma, moreover, its up-regulation was associated with lymph nodes

Table 1. The characteristics of different categories of circRNAs.

\begin{tabular}{|c|c|c|c|c|c|}
\hline Name & Origin & Location & Sequence feature & Major function & Reference \\
\hline $\begin{array}{l}\text { ecRNA/ } \\
\text { ecircRNA }\end{array}$ & exon & cytoplasms & $\begin{array}{l}\text { Formed by cyclization of exons } \\
\text { containing the reverse complemen- } \\
\text { tary sequence of introns and selec- } \\
\text { tive cyclisation; joint site: } 3^{\prime}-5^{\prime} \\
\text { phosphodiester bond }\end{array}$ & $\begin{array}{l}\text { miRNa or RBP } \\
\text { sponge; regulation } \\
\text { translation }\end{array}$ & $\begin{array}{l}\text { Zhang X. et al, } \\
\text { 2014. [24] }\end{array}$ \\
\hline EIciRNA & exon and intron & $\begin{array}{l}\text { nucleus } \\
\text { cytoplasms }\end{array}$ & $\begin{array}{l}\text { Formed by cyclization of exons } \\
\text { containing the reverse complemen- } \\
\text { tary sequence of introns and selec- } \\
\text { tive cyclisation; joint site: } 3^{\prime}-5^{\prime} \\
\text { phosphodiester bond }\end{array}$ & \begin{tabular}{|l} 
Enhance \\
transcription of \\
the parental genes
\end{tabular} & \begin{tabular}{|l|} 
Li Z. et al, 2017 \\
{$[26]$}
\end{tabular} \\
\hline 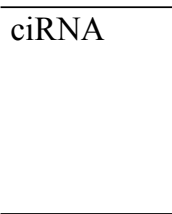 & intron & $\begin{array}{l}\text { nucleus } \\
\text { cytoplasms }\end{array}$ & $\begin{array}{l}\text { 7-nt GU-rich element close to the } \\
\text { 5-splice site and an } 11 \text {-nt C-rich } \\
\text { element near the branch point; } \\
\text { joint site: } 2^{\prime}-5^{\prime} \text { phosphodiester } \\
\text { bond }\end{array}$ & $\begin{array}{l}\text { Regulation oRNA } \\
\text { pol II transcrip- } \\
\text { tion; Regulation } \\
\text { transcription of } \\
\text { parental genes }\end{array}$ & $\begin{array}{l}\text { Zhang Y. et al, } \\
2013 \text { [25] }\end{array}$ \\
\hline $\begin{array}{l}\text { intergenic } \\
\text { circRNA }\end{array}$ & $\begin{array}{l}\text { intronic } \\
\text { circRNA } \\
\text { fragment }\end{array}$ & NA & $\begin{array}{l}\text { Formed by two intronic circRNA } \\
\text { fragments (ICFs) flanked by GT- } \\
\text { AG splicing signals acting as the } \\
\text { splice donor (SD) and splice accep- } \\
\text { tor (SA) of the circular junction. }\end{array}$ & NA & $\begin{array}{l}\text { Gao Y. et al, } 2015 \\
{[27]}\end{array}$ \\
\hline $\begin{array}{l}\text { interior } \\
\text { circRNA/ } \\
\text { i-circRNAs }\end{array}$ & $\begin{array}{l}\text { interior regions } \\
\text { of exon, intron, } \\
\text { and intergenic } \\
\text { transcript } \\
\end{array}$ & NA & $\begin{array}{l}\text { Back fusion points associated with } \\
\text { motif AC/CT }\end{array}$ & $\begin{array}{l}\text { Disgulation in } \\
\text { Alzheimer's Dis- } \\
\text { ease }\end{array}$ & \begin{tabular}{|l} 
Liu X. et al, 2020 \\
{$[28]$}
\end{tabular} \\
\hline $\begin{array}{l}\text { Antisense } \\
\text { circRNA }\end{array}$ & $\begin{array}{l}\text { exon, that } \\
\text { transcribe from } \\
\text { the opposite } \\
\text { strand }\end{array}$ & cytoplasms & Cyclisation of exons & $\begin{array}{l}\text { miRNa sponge; } \\
\text { ribosomal } \mathrm{RNa} \\
\text { maturation }\end{array}$ & $\begin{array}{l}\text { Memczak S. et al, } \\
2013[4]\end{array}$ \\
\hline TricRNA & intron & NA & $\begin{array}{l}\text { Splising pre-tRNA intron an the } \\
\text { bulge-helix-bulge (BHB) splicing } \\
\text { motif by tRNA splicing endonucle- } \\
\text { ase (TSEN); joint site: } 3^{\prime}-5^{\prime} \text { phos- } \\
\text { phodiester bond }\end{array}$ & NA & \begin{tabular}{|l} 
Lu Z. et al, 2015 \\
{$[29]$}
\end{tabular} \\
\hline $\begin{array}{l}\text { Fusion } \\
\text { circRNA }\end{array}$ & $\begin{array}{l}\text { exons of distinct } \\
\text { genes }\end{array}$ & NA & $\begin{array}{l}\text { Produced from transcribed } \\
\text { exons of distinct genes affected } \\
\text { by aberrant chromosomal } \\
\text { translocations }\end{array}$ & $\begin{array}{l}\text { Disgulation in } \\
\text { cancer }\end{array}$ & $\begin{array}{l}\text { Guarnerio J. et al, } \\
2016[30]\end{array}$ \\
\hline
\end{tabular}

Note: NA - no avaliable 
invasion, metastasis and poor survival prognosis. Due to the absence of significant upregulation of circPRMT5 in several other studied cancers, it was supposed, that high level of this circular transcript may be specific for bladder cancer. It was shown, that circPRMT5 can be found in serum and urine exosomes from bladder cancer patients and its high level here is associated with metastasis and poor prognosis. Due to those data, circPRMT5 was proposed as potential novel target for anticancer therapy [111].

Zhang et al. identified the 87-amino-acid peptide, encoded by the circular form of the long intergenic non-protein-coding RNA p53induced transcript (LINC-PINT). The expression of this peptide and its corresponding circRNA was decreased in glioblastoma compared to normal tissues. The authors demonstrated the ability of this transcript to suppress glioblastoma cells' proliferation in vitro and in vivo by direct interaction with polymerase associated factor complex (PAF1c) following the inhibition of numerous oncogenes' transcription [112].

The circular RNAs derived from viruses play exceptional role in cancer development. In 2018 Tuna Toptan et al. claimed the discovery of circRNAs in Epstein-Barr virus (EBV) and Kaposi's sarcoma herpesvirus (KSHV). Their experiments demonstrated, that either EBV or KSHV both encodes circRNAs, which are stably expressed in tumors, associated with these viruses. EBV abundantly expressed both exon-only and exon-intron circRNAs from the BamHI A rightward transcript (BART) locus (circBARTs). KSHV polyadenylated nuclear (PAN) RNA locus generated a swarm $(>100)$ of multiply backspliced, low-abundance RNase
R-resistant circRNAs originating in both sense and antisense directions [113].

At the same year Ungerleider with coauthors published their article about EBV circRNAome. Using cell lines models of types I, II and III EBV latency in B-cell lymphomas and gastric cancers, they discovered, that EBV expresses numerous circRNAs, in both latency and reactivation. For instance, circRPMS1 E4_E3a and circRPMS1_E4_E2 are expressed in latency and have been detected in virusassociated patient tumor samples. Moreover, the majority of viral circRNAs, identified in their study, had the expression level similar or even higher, compared to cellular circRNAs. Also authors suggest, that the stress of transcription machinery during viral reactivation leads to increasing accidence of backsplicing compared to canonical splicing, thus, resulting in abundance of viral circular transcripts [114]. All these data place the viral circular RNAs as the potential biomarkers of virus-associated cancers.

It is no doubt, that cancer-related circRNAs and peptides, encoded by circRNAs, show a great potential as diagnostic markers, prognostic indicators and therapeutic targets for cancer treatment $[115,116]$. The comprehensive detection of different circRNAs and traditional markers may result in the higher diagnostic efficiency [117]. Nevertheless, the further investigations are needed to understand their mechanisms of action and the role in carcinogenesis.

\section{Conclusions and Perspectives}

Summarizing all information given above, circRNAs function as regulators of the pivotal cellular processes, e.g. transcription and trans- 
lation; they can act alone, together with proteins and even be translated to peptides themselves. Thus, we can conclude, that the noncoding RNA community now is supplemented with new powerful member, which demonstrates amazing and diverse potential and functions.

Circular RNAs, although discovered several decades ago, stayed in the shadow for a lot of time, and only the research of 2010's uncovered their emerging capabilities. Participation in numerous cellular pathways and engagement in various physiological processes put them in a row with other non-coding RNAs, such as microRNAs, piwiRNAs, lncRNAs and others. Being the players in the development and aging processes, pathological conditions, such as cancer and other diseases, circular RNAs can serve as potential markers and, maybe, even therapy targets. Moreover, their presence in exosomes makes them probable markers for non-invasive diagnostics.

Nevertheless, a lot of questions (including the nuances of circular RNA biogenesis, the functions of different types of circRNAs, their interactions with microRNAs, proteins and other biomolecules) remain unrevealed yet. Therefore, further investigation is needed for better understanding of these RNAs to comprise the full picture of their role in living organisms.

\section{REFERENCES}

1. Mohr AM, Mott JL. Overview of microRNA biology. Semin Liver Dis. 2015;35(1):3-11.

2. Gordiuk $V V$. [Long Non-Coding RNAs--"tuning Fork" in Regulation of Cell Processes] Ukr Biochem J. 2014;86(2):5-15.
3. Wilusz JE, Sharp PA. Molecular biology. A circuitous route to noncoding RNA. Science. 2013; 340(6131):440-1.

4. Memczak S, Jens M, Elefsinioti A, Torti F, Krueger J, Rybak A, Maier L, Mackowiak SD, Gregersen LH, Munschauer M, Loewer A, Ziebold U, Landthaler M, Kocks C, le Noble F, Rajewsky N. Circular RNAs are a large class of animal RNAs with regulatory potency. Nature. 2013; 495(7441): 333-8.

5. Diener TO, Raymer WB. Potato spindle tuber virus: a plant virus with properties of a free nucleic acid. Science. 1967;158(3799):378-81.

6. Sanger HL, Klotz G, Riesner D, Gross HJ, Kleinschmidt $A K$. Viroids are single-stranded covalently closed circular RNA molecules existing as highly base-paired rod-like structures. Proc Natl Acad Sci U S A. 1976;73(11):3852-6.

7. Kolakofsky D. Isolation and characterization of Sendai virus DI-RNAs. Cell. 1976;8(4):547-55.

8. Kos A, Dijkema R, Arnberg AC, van der Meide PH, Schellekens $H$. The hepatitis delta (delta) virus possesses a circular RNA. Nature. 1986-15; 323(6088):558-60.

9. Lempp FA, Urban S. Hepatitis Delta Virus: Replication Strategy and Upcoming Therapeutic Options for a Neglected Human Pathogen. Viruses. 2017;9(7):172.

10. Weiner AJ, Choo QL, Wang KS, Govindarajan $S$, Redeker AG, Gerin JL, Houghton M. A single antigenomic open reading frame of the hepatitis delta virus encodes the epitope(s) of both hepatitis delta antigen polypeptides p24 delta and p27 delta. $J$ Virol. 1988;62(2):594-9.

11. Kjems J, Garrett RA. Novel splicing mechanism for the ribosomal RNA intron in the archaebacterium Desulfurococcus mobilis. Cell. 1988;54(5): 693-703.

12. Salgia SR, Singh SK, Gurha P, Gupta R. Two reactions of Haloferax volcanii RNA splicing enzymes: joining of exons and circularization of introns. RNA. 2003;9(3):319-30.

13. Danan M, Schwartz S, Edelheit S, Sorek R. Transcriptome-wide discovery of circular RNAs in Archaea. Nucleic Acids Res. 2012;40(7):3131-42. 
14. Hsu MT, Coca-Prados M. Electron microscopic evidence for the circular form of RNA in the cytoplasm of eukaryotic cells. Nature. 1979;280(5720): 339-40.

15. Grabowski PJ, Zaug AJ, Cech TR. The intervening sequence of the ribosomal RNA precursor is converted to a circular RNA in isolated nuclei of Tetrahymena. Cell. 1981;23(2):467-76.

16. Broadbent KM, Broadbent JC, Ribacke U, Wirth D, Rinn JL, Sabeti PC. Strand-specific RNA sequencing in Plasmodium falciparum malaria identifies developmentally regulated long non-coding RNA and circular RNA. BMC Genomics. 2015;16(1):454.

17. Huo L, Zhang P, Li C, Rahim K, Hao X, Xiang B, $Z h u X$. Genome-Wide Identification of circRNAs in Pathogenic Basidiomycetous Yeast Cryptococcus neoformans Suggests Conserved circRNA Host Genes over Kingdoms. Genes (Basel). 2018;9(3):118.

18. Soma A, Onodera A, Sugahara J, Kanai A, Yachie N, Tomita M, Kawamura F, Sekine Y. Permuted tRNA genes expressed via a circular RNA intermediate in Cyanidioschyzon merolae. Science. 2007;318(5849): 450-3. Erratum in: Science. 2007;318(5858): 1866.

19. Nigro JM, Cho KR, Fearon ER, Kern SE, Ruppert JM, Oliner JD, Kinzler KW, Vogelstein B. Scrambled exons. Cell. 1991;64(3):607-13.

20. Cocquerelle C, Mascrez B, Hétuin D, Bailleul B. Mis-splicing yields circular RNA molecules. FASEB J. 1993;7(1):155-60.

21. Salzman J, Gawad C, Wang PL, Lacayo N, Brown PO. Circular RNAs are the predominant transcript isoform from hundreds of human genes in diverse cell types. PLoS One. 2012;7(2):e30733.

22. Ebbesen $K K$, Hansen TB, Kjems $J$. Insights into circular RNA biology. RNA Biol. 2017;14(8):1035-45.

23. Guo JU, Agarwal V, Guo H, Bartel DP. Expanded identification and characterization of mammalian circular RNAs. Genome Biol. 2014;15(7):409.

24. Zhang XO, Wang HB, Zhang $Y$, Lu X, Chen LL, Yang $L$. Complementary sequence-mediated exon circularization. Cell. 2014;159(1):134-47.

25. Zhang $Y$, Zhang XO, Chen T, Xiang JF, Yin $Q F$, Xing YH, Zhu S, Yang L, Chen LL. Circular intronic long noncoding RNAs. Mol Cell. 2013 Sep 26;51(6):792-806
26. Li Z, Huang C, Bao C, Chen L, Lin M, Wang X, Zhong G, Yu B, Hu W, Dai L, Zhu P, Chang Z, Wu Q, Zhao Y, Jia Y, Xu P, Liu H, Shan G. Exonintron circular RNAs regulate transcription in the nucleus. Nat Struct Mol Biol. 2015;22(3):256-64.

27. Gao Y, Wang J, Zhao F. CIRI: an efficient and unbiased algorithm for de novo circular RNA identification. Genome Biol. 2015;16(1):4.

28. Liu X, Hu Z, Zhou J, Tian C, Tian G, He M, Gao L, Chen L, Li T, Peng H, Zhang $W$. Interior circular RNA. RNA Biol. 2020;17(1):87-97.

29. Lu Z, Filonov GS, Noto JJ, Schmidt CA, Hatkevich TL, Wen Y, Jaffrey SR, Matera AG. Metazoan tRNA introns generate stable circular RNAs in vivo. RNA. 2015;21(9):1554-65.

30. Guarnerio J, Bezzi M, Jeong JC, Paffenholz SV, Berry K, Naldini MM, Lo-Coco F, Tay Y, Beck AH, Pandolfi PP. Oncogenic Role of Fusion-circRNAs Derived from Cancer-Associated Chromosomal Translocations. Cell. 2016;165(2):289-302.

31. Qian L, Yu S, Chen Z, Meng Z, Huang S, Wang P. The emerging role of circRNAs and their clinical significance in human cancers. Biochim Biophys Acta Rev Cancer. 2018;1870(2):247-60.

32. Eger N, Schoppe L, Schuster S, Laufs U, Boeckel JN. Circular RNA Splicing. Adv Exp Med Biol. 2018;1087:41-52.

33. Lasda E, Parker R. Circular RNAs: diversity of form and function. RNA. 2014;20(12):1829-42.

34. Ding L, Zhao Y, Dang S, Wang Y, Li X, Yu X, Li Z, Wei J, Liu $M, L i$ G. Circular RNA circ-DONSON facilitates gastric cancer growth and invasion via NURF complex dependent activation of transcription factor SOX4. Mol Cancer. 2019;18(1):45.

35. Enuka Y, Lauriola M, Feldman ME, Sas-Chen A, Ulitsky I, Yarden Y. Circular RNAs are long-lived and display only minimal early alterations in response to a growth factor. Nucleic Acids Res. 2016;44(3):1370-83.

36. Schwanhäusser B, Busse D, Li N, Dittmar G, Schuchhardt J, Wolf J, Chen W, Selbach M. Global quantification of mammalian gene expression control. Nature. 2011;473(7347):337-42.

37. Rybak-Wolf A, Stottmeister C, Glažar P, Jens $M$, Pino N, Giusti S, Hanan M, Behm M, Bartok O, 
Ashwal-Fluss R, Herzog M, Schreyer L, Papavasileiou P, Ivanov A, Öhman M, Refojo D, Kadener $S$, Rajewsky N. Circular RNAs in the Mammalian Brain Are Highly Abundant, Conserved, and Dynamically Expressed. Mol Cell. 2015;58(5):870-85.

38. Holdt LM, Kohlmaier A, Teupser D. Molecular roles and function of circular RNAs in eukaryotic cells. Cell Mol Life Sci. 2018;75(6):1071-98.

39. Huang $C$, Liang D, Tatomer DC, Wilusz JE. A length-dependent evolutionarily conserved pathway controls nuclear export of circular RNAs. Genes Dev. 2018;32(9-10):639-44.

40. Liang D, Wilusz JE. Short intronic repeat sequences facilitate circular RNA production. Genes Dev. 2014;28(20):2233-47.

41. Yang L, Fu J, Zhou Y. Circular RNAs and Their Emerging Roles in Immune Regulation. Front Immunol. 2018;9:2977.

42. Dong $R, M a X K$, Chen LL, Yang L. Increased complexity of circRNA expression during species evolution. RNA Biol. 2017;14(8):1064-74.

43. Jeck WR, Sorrentino JA, Wang K, Slevin MK, Burd CE, Liu J, Marzluff WF, Sharpless NE. Circular RNAs are abundant, conserved, and associated with ALU repeats. RNA. 2013;19(2):141-57.

44. Dubin RA, Kazmi MA, Ostrer $H$. Inverted repeats are necessary for circularization of the mouse testis Sry transcript. Gene. 1995;167(1-2):245-8.

45. Wilusz JE. Repetitive elements regulate circular RNA biogenesis. Mob Genet Elements. 2015; 5(3):1-7.

46. Chen L, Zhang P, Fan Y, Lu Q, Li Q, Yan J, Muehlbauer GJ, Schnable PS, Dai M, Li L. Circular RNAs mediated by transposons are associated with transcriptomic and phenotypic variation in maize. New Phytol. 2018;217(3):1292-306.

47. de la Peña M. Circular RNAs Biogenesis in Eukaryotes Through Self-Cleaving Hammerhead Ribozymes. Adv Exp Med Biol. 2018;1087:53-63.

48. Alhasan AA, Izuogu OG, Al-Balool HH, Steyn JS, Evans A, Colzani M, Ghevaert C, Mountford JC, Marenah L, Elliott DJ, Santibanez-Koref M, Jackson MS. Circular RNA enrichment in platelets is a signature of transcriptome degradation. Blood. 2016;127(9):e1-e11.
49. Memczak S, Papavasileiou P, Peters O, Rajewsky N. Identification and Characterization of Circular RNAs As a New Class of Putative Biomarkers in Human Blood. PLoS One. 2015;10(10):e0141214.

50. Vea A, Llorente-Cortes $V$, de Gonzalo-Calvo D. Circular RNAs in Blood. Adv Exp Med Biol. 2018;1087:119-30.

51. Li Y, Zheng Q, Bao C, Li S, Guo W, Zhao J, Chen D, $G u J$, He X, Huang $S$. Circular RNA is enriched and stable in exosomes: a promising biomarker for cancer diagnosis. Cell Res. 2015;25(8):981-4.

52. Wang ET, Sandberg R, Luo S, Khrebtukova I, Zhang L, Mayr C, Kingsmore $S F$, Schroth GP, Burge CB. Alternative isoform regulation in human tissue transcriptomes. Nature. 2008;456(7221):470-6.

53. Aebi M, Hornig H, Weissmann C. 5' cleavage site in eukaryotic pre-mRNA splicing is determined by the overall 5' splice region, not by the conserved 5' GU. Cell. 1987;50(2):237-46.

54. Barrett SP, Wang PL, Salzman J. Circular RNA biogenesis can proceed through an exon-containing lariat precursor. Elife. 2015;4:e07540.

55. Kramer MC, Liang D, Tatomer DC, Gold B, March ZM, Cherry S, Wilusz JE. Combinatorial control of Drosophila circular RNA expression by intronic repeats, hnRNPs, and SR proteins. Genes Dev. 2015;29(20):2168-82.

56. Ashwal-Fluss R, Meyer M, Pamudurti NR, Ivanov A, Bartok O, Hanan M, Evantal N, Memczak S, Rajewsky N, Kadener $S$. circRNA biogenesis competes with pre-mRNA splicing. Mol Cell. 2014;56(1):55-66.

57. Arnaiz E, Sole C, Manterola L, Iparraguirre L, Otaegui D, Lawrie CH. CircRNAs and cancer: Biomarkers and master regulators. Semin Cancer Biol. 2019;58:90-9.

58. Azmi AS. Nuclear export mechanisms of circular RNAs: size does matter. Noncoding RNA Investig. 2018;2:52.

59. Hansen TB, Wiklund ED, Bramsen JB, Villadsen $S B$, Statham AL, Clark SJ, Kjems J. miRNAdependent gene silencing involving Ago2-mediated cleavage of a circular antisense RNA. EMBO J. 2011;30(21):4414-22.

60. Zhou C, Molinie B, Daneshvar K, Pondick JV, Wang J, Van Wittenberghe N, Xing Y, Gialloura- 
kis CC, Mullen AC. Genome-Wide Maps of m6A circRNAs Identify Widespread and Cell-TypeSpecific Methylation Patterns that Are Distinct from mRNAs. Cell Rep. 2017;20(9):2262-76.

61. Lasda E, Parker R. Circular RNAs Co-Precipitate with Extracellular Vesicles: A Possible Mechanism for circRNA Clearance. PLoS One. 2016;11(2): $\mathrm{e} 0148407$.

62. Du WW, Zhang C, Yang $W$, Yong T, Awan FM, Yang BB. Identifying and Characterizing circRNA-Protein Interaction. Theranostics. 2017;7(17):4183-91.

63. Lunde BM, Moore C, Varani G. RNA-binding proteins: modular design for efficient function. Nat Rev Mol Cell Biol. 2007;8(6):479-90.

64. Janas T, Janas MM, Sapoń K, Janas T. Mechanisms of RNA loading into exosomes. FEBS Lett. 2015;589(13):1391-8.

65. Ivanov A, Memczak S, Wyler E, Torti F, Porath HT, Orejuela MR, Piechotta M, Levanon EY, Landthaler M, Dieterich C, Rajewsky N. Analysis of intron sequences reveals hallmarks of circular RNA biogenesis in animals. Cell Rep. 2015;10(2):170-7.

66. Aktaş T, Avşar Ilik I, Maticzka D, Bhardwaj V, Pessoa Rodrigues C, Mittler G, Manke T, Backofen R, Akhtar A. DHX9 suppresses RNA processing defects originating from the Alu invasion of the human genome. Nature. 2017;544(7648):115-9.

67. Errichelli L, Dini Modigliani S, Laneve P, Colantoni A, Legnini I, Capauto D, Rosa A, De Santis R, Scarfò R, Peruzzi G, Lu L, Caffarelli E, Shneider NA, Morlando M, Bozzoni I. FUS affects circular RNA expression in murine embryonic stem cell-derived motor neurons. Nat Commun. 2017;8:14741.

68. Liang D, Tatomer DC, Luo Z, Wu H, Yang L, Chen LL, Cherry S, Wilusz JE. The Output of Protein-Coding Genes Shifts to Circular RNAs When the Pre-mRNA Processing Machinery Is Limiting. Mol Cell. 2017;68(5):940-954.e3.

69. Fei T, Chen Y, Xiao T, Li W, Cato L, Zhang P, Cotter $M B$, Bowden $M$, Lis RT, Zhao SG, Wu $Q$, Feng FY, Loda M, He HH, Liu XS, Brown M. Genome-wide CRISPR screen identifies HNRNPL as a prostate cancer dependency regulating RNA splicing. Proc Natl Acad Sci U S A. 2017;114(26):E5207E5215.
70. Conn SJ, Pillman KA, Toubia J, Conn VM, Salmanidis $M$, Phillips CA, Roslan S, Schreiber AW, Gregory $P A$, Goodall GJ. The RNA binding protein quaking regulates formation of circRNAs. Cell. 2015;160(6):1125-34.

71. Abdelmohsen K, Panda AC, Munk R, Grammatikakis I, Dudekula DB, De S, Kim J, Noh JH, Kim KM, Martindale JL, Gorospe M. Identification of HuR target circular RNAs uncovers suppression of PABPN1 translation by CircPABPN1. RNA Biol. 2017;14(3):361-9.

72. Hansen TB, Jensen TI, Clausen BH, et al. Natural RNA circles function as efficient microRNA sponges. Nature. 2013;495(7441):384-8.

73. Yang ZG, Awan FM, Du WW, Zeng Y, Lyu J, Wu D, Gupta $S$, Yang $W$, Yang BB. The Circular RNA Interacts with STAT3, Increasing Its Nuclear Translocation and Wound Repair by Modulating Dnmt3a and miR-17 Function. Mol Ther. 2017; 25(9):2062-74.

74. Du WW, Yang $W$, Chen $Y, W u Z K$, Foster FS, Yang Z, $L i X$, Yang BB. Foxo3 circular RNA promotes cardiac senescence by modulating multiple factors associated with stress and senescence responses. Eur Heart J. 2017;38(18):1402-12.

75. Du WW, Fang L, Yang $W$, Wu N, Awan FM, Yang Z, Yang $B B$. Induction of tumor apoptosis through a circular RNA enhancing Foxo3 activity. Cell Death Differ. 2017;24(2):357-70.

76. Du $W W$, Yang $W$, Liu E, Yang Z, Dhaliwal P, Yang $B B$. Foxo3 circular RNA retards cell cycle progression via forming ternary complexes with p21 and CDK2. Nucleic Acids Res. 2016;44(6):2846-58.

77. O'Leary VB, Smida J, Matjanovski M, Brockhaus C, Winkler K, Moertl S, Ovsepian SV, Atkinson MJ. The circRNA interactome-innovative hallmarks of the intra- and extracellular radiation response. Oncotarget. 2017;8(45):78397-409.

78. Ung TH, Madsen HJ, Hellwinkel JE, Lencioni AM, Graner $M W$. Exosome proteomics reveals transcriptional regulator proteins with potential to mediate downstream pathways. Version 2. Cancer Sci. 2014;105(11):1384-92.

79. Yang C, Wu D, Gao L, Liu X, Jin Y, Wang D, Wang $T$, Li X. Competing endogenous RNA net- 
works in human cancer: hypothesis, validation, and perspectives. Oncotarget. 2016;7(12):13479-90.

80. Wang K, Sun Y, Tao W, Fei X, Chang C. Androgen receptor (AR) promotes clear cell renal cell carcinoma (ccRCC) migration and invasion via altering the circHIAT1/miR-195-5p/29a-3p/29c-3p/CDC42 signals. Cancer Lett. 2017;394:1-12.

81. Conn VM, Hugouvieux V, Nayak A, Conos SA, Capovilla G, Cildir G, Jourdain A, Tergaonkar V, Schmid M, Zubieta C, Conn SJ. A circRNA from SEPALLATA3 regulates splicing of its cognate mRNA through R-loop formation. Nat Plants. 2017;3:17053.

82. Xu S, Zhou L, Ponnusamy M, Zhang L, Dong Y, Zhang Y, Wang $Q$, Liu J, Wang K. A comprehensive review of circRNA: from purification and identification to disease marker potential. PeerJ. 2018;6:e5503.

83. Pamudurti NR, Bartok O, Jens M, Ashwal-Fluss R, Stottmeister C, Ruhe L, Hanan M, Wyler E, PerezHernandez D, Ramberger E, Shenzis S, Samson M, Dittmar G, Landthaler M, Chekulaeva M, Rajewsky N, Kadener S. Translation of CircRNAs. Mol Cell. 2017;66(1):9-21.e7.

84. Yang $Y$, Fan $X$, Mao $M$, Song $X$, Wu P, Zhang $Y$, Jin Y, Yang Y, Chen LL, Wang Y, Wong CC, Xiao X, Wang Z. Extensive translation of circular RNAs driven by N6-methyladenosine. Cell Res. 2017; 27(5):626-41.

85. Diallo LH, Tatin F, David F, Godet AC, Zamora A, Prats AC, Garmy-Susini B, Lacazette E. How are circRNAs translated by non-canonical initiation mechanisms? Biochimie. 2019;164:45-52.

86. Yang $Y$, Gao $X$, Zhang $M$, Yan $S$, Sun $C$, Xiao $F$, Huang $N$, Yang X, Zhao K, Zhou H, Huang S, Xie B, Zhang $N$. Novel Role of FBXW7 Circular RNA in Repressing Glioma Tumorigenesis. J Natl Cancer Inst. 2018;110(3):304-15.

87. Holdt LM, Stahringer A, Sass K, Pichler G, Kulak NA, Wilfert $W$, Kohlmaier A, Herbst A, Northoff BH, Nicolaou A, Gäbel G, Beutner F, Scholz M, Thiery J, Musunuru K, Krohn K, Mann M, Teupser $D$. Circular non-coding RNA ANRIL modulates ribosomal RNA maturation and atherosclerosis in humans. Nat Commun. 2016;7:12429.
88. Jie $M$, Wu Y, Gao $M$, Li $X$, Liu C, Ouyang $Q$, Tang $Q$, Shan $C$, Lv Y, Zhang $K$, Dai $Q$, Chen $Y$, Zeng $S$, Li C, Wang L, He F, Hu C, Yang S. CircMRPS35 suppresses gastric cancer progression via recruiting KAT7 to govern histone modification. Mol Cancer. 2020;19(1):56.

89. Dong $R$, Zhang XO, Zhang Y, Ma XK, Chen LL, Yang L. CircRNA-derived pseudogenes. Cell Res. 2016;26(6):747-50.

90. Knupp D, Miura P. CircRNA accumulation: A new hallmark of aging? Mech Ageing Dev. 2018;173:71-9.

91. Maiese $K$. Disease onset and aging in the world of circular RNAs. J Transl Sci. 2016;2(6):327-9.

92. Akhter R. Circular RNA and Alzheimer's Disease. Adv Exp Med Biol. 2018;1087:239-43.

93. Li M, Ding W, Sun T, Tariq MA, Xu T, Li P, Wang J. Biogenesis of circular RNAs and their roles in cardiovascular development and pathology. FEBS J. 2018;285(2):220-32.

94. Yan L, Feng J, Cheng F, Cui X, Gao L, Chen Y, Wang F, Zhong T, Li Y, Liu L. Circular RNA expression profiles in placental villi from women with gestational diabetes mellitus. Biochem Biophys Res Commun. 2018;498(4):743-50.

95. Bach DH, Lee SK, Sood AK. Circular RNAs in Cancer. Mol Ther Nucleic Acids. 2019;16:118-129.

96. Liang G, Yang Y, Niu G, Tang Z, Li K. Genomewide profiling of Sus scrofa circular RNAs across nine organs and three developmental stages. DNA Res. 2017;24(5):523-35.

97. Zhang P, Chao Z, Zhang R, Ding R, Wang $Y, W u W$, Han $Q, L i C, X u H$, Wang $L, X u Y$. Circular RNA Regulation of Myogenesis. Cells. 2019;8(8):885.

98. Li $M$, Ding $W$, Tariq $M A$, Chang $W$, Zhang $X, X u W$, Hou L, Wang Y, Wang J. A circular transcript of ncx 1 gene mediates ischemic myocardial injury by targeting miR-133a-3p. Theranostics. 2018;8(21):5855-69.

99. Sekar S, Liang WS. Circular RNA expression and function in the brain. Noncoding RNA Res. 2019;4(1):23-29.

100.Chen BJ, Huang S, Janitz M. Changes in circular RNA expression patterns during human foetal brain development. Genomics. 2019;111(4):753-8.

101.Chen YG, Kim MV, Chen X, Batista PJ, Aoyama S, Wilusz JE, Iwasaki A, Chang HY. Sensing Self and 
Foreign Circular RNAs by Intron Identity. Mol Cell. 2017;67(2):228-238.e5.

102.Li X, Liu CX, Xue W, Zhang Y, Jiang S, Yin QF, Wei J, Yao $R W$, Yang $L$, Chen LL. Coordinated circRNA Biogenesis and Function with NF90/NF110 in Viral Infection. Mol Cell. 2017;67(2):214-227.e7.

103.Harashima A, Guettouche T, Barber GN. Phosphorylation of the NFAR proteins by the dsRNAdependent protein kinase PKR constitutes a novel mechanism of translational regulation and cellular defense. Genes Dev. 2010;24(23):2640-53.

104.Ng WL, Marinov GK, Liau ES, Lam YL, Lim YY, $E a C K$. Inducible RasGEF1B circular RNA is a positive regulator of ICAM-1 in the TLR4/LPS pathway. RNA Biol. 2016;13(9):861-71.

105.Yang L, Fu J, Zhou Y. Circular RNAs and Their Emerging Roles in Immune Regulation. Front Immunol. 2018;9:2977.

106.Zhang Y, Zhang Y, Li X, Zhang M, Lv K. Microarray analysis of circular RNA expression patterns in polarized macrophages. Int J Mol Med. 2017;39(2):373-9.

107.Guarnerio J, Bezzi M, Jeong JC, Paffenholz SV, Berry K, Naldini MM, Lo-Coco F, Tay Y, Beck AH, Pandolfi PP. Oncogenic Role of Fusion-circRNAs Derived from Cancer-Associated Chromosomal Translocations. Cell. 2016;165(2):289-302. Erratum in: Cell. 2016;166(4):1055-6.

108. Yang $Q, D u W W, W u N$, Yang $W$, Awan FM, Fang $L$, Ma J, Li X, Zeng Y, Yang Z, Dong J, Khorshidi A, Yang $B B$. A circular RNA promotes tumorigenesis by inducing c-myc nuclear translocation. Cell Death Differ. 2017;24(9):1609-20.

109. Greene J, Baird AM, Brady L, Lim M, Gray SG, McDermott R, Finn SP. Circular RNAs: Biogenesis, Function and Role in Human Diseases. Front Mol Biosci. 2017;4:38.

110.Meng J, Chen S, Han JX, Qian B, Wang XR, Zhong WL, Qin Y, Zhang H, Gao WF, Lei YY, Yang W, Yang L, Zhang C, Liu HJ, Liu YR, Zhou HG, Sun T, Yang $C$. Twist1 Regulates Vimentin through Cul2 Circular RNA to Promote EMT in Hepatocellular Carcinoma. Cancer Res. 2018;78(15):4150-62.

111. Chen X, Chen RX, Wei WS, Li YH, Feng ZH, Tan L, Chen JW, Yuan GJ, Chen SL, Guo SJ, Xiao KH, Liu ZW, Luo JH, Zhou FJ, Xie D. PRMT5 Circular
RNA Promotes Metastasis of Urothelial Carcinoma of the Bladder through Sponging miR-30c to Induce Epithelial-Mesenchymal Transition. Clin Cancer Res. 2018;24(24):6319-30.

112.Zhang $M$, Zhao $K, X u X$, Yang $Y$, Yan $S$, Wei $P$, Liu H, Xu J, Xiao F, Zhou H, Yang X, Huang $N$, Liu J, He K, Xie K, Zhang G, Huang S, Zhang N. A peptide encoded by circular form of LINC-PINT suppresses oncogenic transcriptional elongation in glioblastoma. Nat Commun. 2018;9(1):4475.

113.Toptan T, Abere B, Nalesnik MA, Swerdlow SH, Ranganathan S, Lee $N$, Shair KH, Moore PS, Chang $Y$. Circular DNA tumor viruses make circular RNAs. Proc Natl Acad Sci U S A. 2018;115(37): E8737-E8745.

114. Ungerleider $N$, Concha $M$, Lin Z, Roberts $C$, Wang X, Cao S, Baddoo M, Moss WN, Yu Y, Seddon M, Lehman T, Tibbetts S, Renne R, Dong Y, Flemington EK. The Epstein Barr virus circRNAome. PLoS Pathog. 2018;14(8):e1007206.

115. Sui W, Shi Z, Xue W, Ou M, Zhu Y, Chen J, Lin H, Liu F, Dai Y. Circular RNA and gene expression profiles in gastric cancer based on microarray chip technology. Oncol Rep. 2017;37(3):1804-14.

116.Zhu S, Wang J, He Y, Meng N, Yan GR. Peptides/ Proteins Encoded by Non-coding RNA: A Novel Resource Bank for Drug Targets and Biomarkers. Front Pharmacol. 2018;9:1295.

117. Geng $Y$, Jiang $J, W u C$. Function and clinical significance of circRNAs in solid tumors. J Hematol Oncol. 2018;11(1):98.

\section{Кільцеві РНК - «кільця влади» над клітиною}

В. В. Гордіюк, О. С. Маньковська

Кільцеві РНК (circRNA) є ендогенними ковалентнозамкненими одноланцюговиминекодуючими РНК (ncRNA), що не мають 5'-КЭПа і 3'-поліаденілювання, які утворюються внаслідок різних варіацій альтернативного сплайсингу мРНК. Експресію кільцевих РНК було виявлено у представників усіх груп еволюційного дерева життя, включаючи віруси та прокаріоти. Ці молекули є еволюційно консервативними. Кільцеві РНК відіграють постійну і універсальну біологічну роль. У даному огляді ми узагальнили останню наявну інформацію про 
кільцеві РНК та виділили їх найважливіші та найкраще вивчені функції в різних біологічних процесах.

Кл юч о в і с л о в а: Кільцеві РНК (circRNA), РНКзвязувальні білки (RBPs), модельбэксплайсинга, модель лассо, циркулююча позаклітинна PHK, circRNA, асоційовани з раком.

Кольцевые РНК - «кольца власти» над клеткой

В. В. Гордиюк, О. С. Маньковская

Кольцевые РНК (circRNA) являются эндогенными ковалентно замкнутыми одноцепочечными некодирующими РНК (ncRNA), не имеющими 5'-КЭПа и 3'-полиаденилирования, которые образуются в результате различных вариаций альтернативного сплайсинга
мРНК. Экспрессию кольцевых РНК было обнаружено у представителей всех групп эволюционного древа жизни, включая вирусы и прокариоты. Эти молекулы являются эволюционно консервативными. Кольцевые РНК играют постоянную и универсальную биологическую роль. В данном обзоре мы обобщили последнюю имеющуюся информацию о кольцевых РНК и выделили их важнейшие и наиболее изученные функции в различных биологических процессах.

Ключевые слова: кольцевые РНК, РНКсвязывающиебелки (RBPs), модельбэксплайсинга, модель лассо, циркулирующаявнеклеточная РНК, circRNA, ассоциированные с раком.

Received 06.10.2019 